\title{
Design Omnidirectional Movement Screw Blade of An Unmanned Mini Tiller
}

\author{
Sukmaji Indro Cahyono ${ }^{1 *}$, Ari Prasetyo ${ }^{1}$
}

Program Studi Teknik Mesin, Universitas Sebelas Maret, Surakarta

*e-mail address: sukmaji@ft.uns.ac.id

\section{Keywords:}

AMC, Stir Casting, Electroless Coating, sifat fisik, sifat mekanik,

\section{PENDAHULUAN}

Rotary tiller, rotavtor atau Minitraktor adalah mesin yang digunakan untuk membajak tanah dengan prinsip kerja memutar serangkaian bilah roda diatas permukaan tanah. Selama beberapa tahun belakangan ini, minitraktor telah menjadi alat penting dalam mengolah tanah sebelum proses tanam pada ladang yang memilik kontur perbukitan/daerah yang sulit di akses dengan traktor besar [1]. Minitraktor yang memiliki keunggulan tersendiri pada struktur yang memiliki portabilitas tinggi, efisiensi dan kinerjanya lebih baik dibanding peralatan konvesional lain [2]. Minitaktor juga dapat digunakan untuk beberapa model atau tipe pengolahan tanah. Meskpun kebutuhan energi relatif tinggi, daya total yang dibutuhkan untuk peralatan ini rendah [3] Desain bilah roda putar menjadi karakteristik minitraktor yang sangat menentukan besar konsumsi dayanya. Sementara itu tingginya kebutuhan energi menjadi masalah utama dalam perkembangan penelitian mesinmesin pertanian.
Banyak peneliti mempelajari kebutuhan kekuatan dan kerja spesifik pada minitraktor rotary dalam kondisi tanah yang berbeda. [4] Dalin dan Pavlov mengembangkan teori untuk memprediksi kebutuhan daya untuk pemotongan, melonggarkan, melempar tanah, selain itu diteliti juga kebutuhan daya, kehilangan daya pada mesin dan daya hambat gesek terhadap gerak maju dan mendorong. [5] Zhuk memodelkan secara matematis untuk memprediksi kebutuhan daya dan pekerjaan spesifik dari minitraktor rotary dan mempelajari lebar kerja per meter dalam kondisi tanah berpasir dan tanah liat. [6] Mandal mempelajari tiga desain rotari tipe $\mathrm{T}$ dari blade tiller dan memperkirakan kinerjanya berdasarkan kebutuhan energi spesifik. Percobaan diperoleh bahwa semakin tinggi kebutuhan energi spesifik, semakin rendah volume tanah yang olah dan biaya operasional pengolahan tanah yang paling efektif dan optimal tercapai. Juga disimpulkan bahwa kontrol kecepatan sudut pada bilah roda minitraktor dan kecepatan gerak maju alat 
minitraktor rotary akan menghasilkan kebutuhan energi spesifik yang lebih baik.

Minitraktor pada dasarnya dapat dihilangkan sistem kemudinya bila menerapkan prinsip roda Mechanum. Seperti pada desain roda robotik terdapat unit mechanum atau roda omnidirectional (roda yang mampu bertindak sebagai sistem kemudi untuk berbelok ke segala arah) yang paling mendekati dengan studi kasus. Hasil penelitian terdahulu pada roda Mecanum diperoleh bahwa, unit tersebut memiliki tiga derajat kebebasan bergerak dalam sebuah pengoperasian prototipe. Robot mengendalikan gerakan unit dengan menggunakan tiga buah roda Mecanum untuk mencapai gerakan omnidirectional dan dikontrol melalui koordinasi arah dan kecepatan putaran roda, tanpa bantuan sistem kemudi. Robot dengan kemampuan omnidirectional dengan mengunakan roda Mecanum secara luas digunakan di berbagai bidang industri karena memiliki fleksibilitas dan struktur yang sederhana dan akurasi gerakan yang baik. Contoh aplikasi robot bergerak omnidirectional yaitu AGV (kendaraan terbimbing otomatis) dengan empat roda Mecanum [8-10]. Pemilihan konfigurasi roda Mecanum menjadi faktor penting untuk dapat bergerak sebagai robot mobile omnidirectional tanpa sistem kemudi. Namun pengaturan roda Mecanum juga mempengaruhi kinerja mobilitas robot [11]. Oleh karena itu, desain roda mekanik harus dianggap sebagai konfigurasi dan memenuhi persyaratan untuk mewujudkan gerakan omnidirectional. Selain itu hal penting lainnya adalah kinerja gerakan, kemampuan kontrol, dan konfigurasi rasionalitas struktural dievaluasi untuk memilih konfigurasi roda Macanum yang optimal.

Penerapan gerak omnidirectional pada prototipe minitraktor yang paling mendekati adalah desain roda spiral. Mekanisme penggerak roda berbentuk spiral telah dipelajari melalui eksperimen oleh [7]. Prototipe bergerak merambat melalui semak-semak kemudian mampu bergerak memutar dengan sendirinya. Roda roda dengan Spiral tersebut mampu menjaga lintasannya saat berputar dan karena roda berbentuk spiral berakibat pada titik kontak dengan tanah menjadi jamak dan bebannya didistribusikan pada ujung sisi spiral. Penelitian tersebut juga menyimpulkan bahwa terjadi hubungan sebab-akibat antara torsi, beban, dan traksi roda. Pada roda berbentuk spiral juga memiliki prinsip kerja yang sama dengan konveyor spiral, sehingga perhitungan matematis fenomena tersebut identik[12-13].

Pada penelitian ini akan dibandingkan kinerja Desain bilah roda minitraktor yang telah ada dengan desain bilah roda spiral yang baru. Akan diteliti pula akurasi lintasan gerakan omnidirectional sehingga tidak dibutuhkan sistem kemudi pada prototipe minitraktor nirawak yang sedang dikembangkan.

\section{PRINSIP KERJA MINITRAKTOR KONVENSIONAL DAN MINITRAKTOR NIR-AWAK}

Minitraktor rotari konvensional sampai ini masih dioperasikan dan dikendalikan dengan tenaga manusia. Prinsip kerjanya adalah kedua roda depan berputar menggerakkan unit prototipe ke arah depan. Pergerak ke arah depan tersebut ditahan oleh sebuah jangkar yang terletak di belakang kedua roda depan yang berakibat permukaan tanah dibawahnya terpotong dan terangkat atau dengan kata lain proses membajak tanah terjadi hingga kelaman tertentu. Kontrol kedalaman tanah diatur oleh tekanan yang dilakukan oleh manusia pada jangkar. Bila dirasa cukup dalam maka tekanan pada jangkar dikurangi dan sedikit demi sedikit minitraktor bergerak maju. Sementara pada proses berbelok tuas kemudi di tarik ke kiri bila traktor akan di belokkan ke kanan begitu pun sebaliknya. Secara umum desain bilah roda pada minitraktor rotary tidak dapat diaplikasikan pada minitraktor Nir-awak dan hal ini menjadi tujuan utama pada penelitian ini untuk mencari desain bilah roda yang sesuai sekaligus sebagai sistem kemudi. Lihat Gambar 1.

Sementara pada minitraktor nirawak terdapat dua roda depan yang berputar menggerakkan unit ke arah depan dan pergerak- 


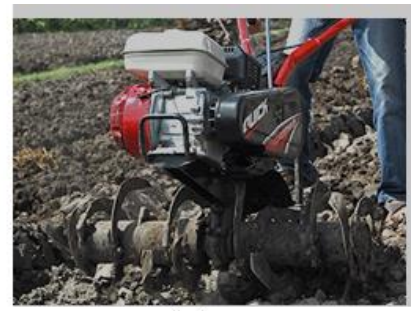

(a)

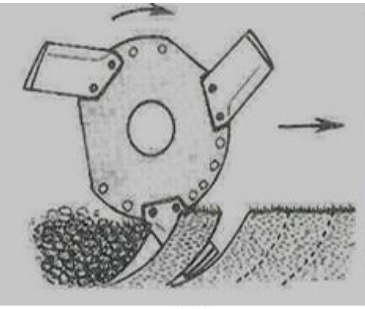

(b)

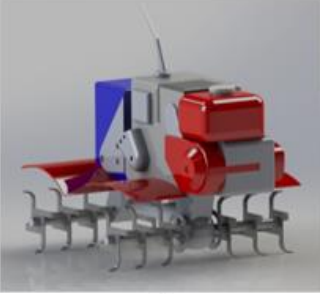

(c)

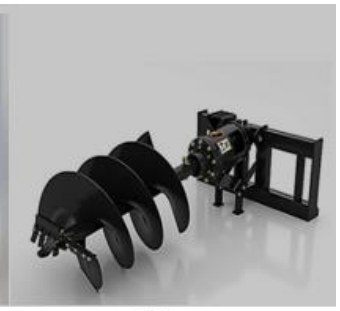

(d)

Gambar 1. Proses penelitian yang telah berlanngsung (a) Roda bilah minitraktor model C yang ada saat ini masih membutuhkan tenaga manusia. (b) Proses pemakanan atau pembajakan tanah yang terpotong oleh bilah roda. (c) Model minitraktor Nir-Awak dengan bilah roda yang sama dengan yang ada di pasaran berjumlah 4 roda tanpa sistem kemudi. (d) Penelitian saat ini mengembangkan desain roda bilah spiral dengan model menyerupai screw conveyor.

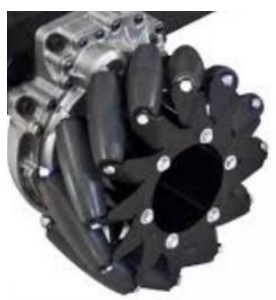

(a)

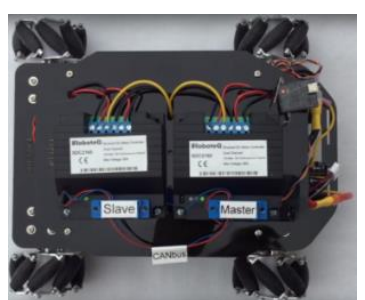

(b)

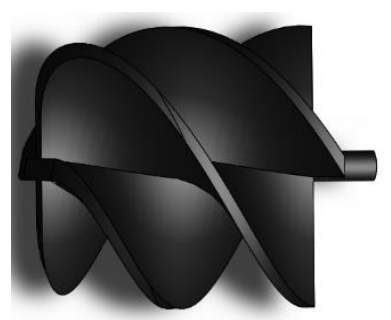

(c)

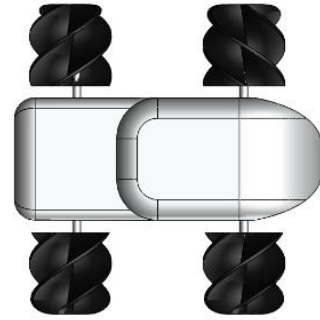

(d)

Gambar 2. Gerak Omnidirectional memungkinkan unit dapat berbelok ke segala arah tanpa sistem kemudi, (a) roda Mechanum yang diaplikasikan pada robot, (b) Robot yang mampu melakukan gerak Omnidirectional dengan rangkaian 4 buah roda mechanum, (c) Bilah roda spiral pada aplikasi minitraktor memiliki prinsip kerja yang sama dengan roda mechanum berbentuk menyerupai screw conveyor, (d) Model Minitraktor Nir-awak tanpa sistem kemudi diperkirakan dapat melakukan gerak Omnidirectional.

kan tersebut tertahan oleh gerak berputar roda belakang yang berlawanan arah dan memiliki kecepatan yang lebih rendah. Sehingga mengakibatkan permukaan tanah terpotong dan terangkat seperti pada proses membajak tanah. Sementara ketika berbelok proses membajak tanah tetap terjadi hanya saja kecepatan putar roda kanan lebih cepat dibanding roda kiri bila unit minitraktor akan berbelok ke kiri. Begitu juga sebaliknya bila roda kiri lebih cepat dibanding roda kanan maka unit mini traktor dapat berbelok ke kanan. Sedangkan bila bilah roda berbentuk spiral maka minitraktor dapat bergeser ke samping (sliding) kiri bila gerak roda kanan searah dengan roda kiri, begitu juga sebaliknya sama seperti prinsip kerja screw conveyor. Fenomena ini sama seperti robot dengan gerak omnidirectional menggunakan roda Mechanum. Mekanisme gerak keempat bilah roda minitraktor dihasilkan dari rangkaian unit clutch, differential gear dan one way bearing, yang telah dibahas dalam penelitian sebelumnya. Sedangkan pada penelitian ini akan di fokuskan pada desain bilah roda spiral dan prediksi kinerja maupun daya yang dibutuhkan. Lihat Gambar 2.

\section{METODE PENDEKATAN MATEMATIS DAN SIMULASI FEA}

Kinerja bilah roda rotari dapat diinterpretasikan sebagai besar kapasitas tanah yang terangkat atau terbajak yang dipengaruhi oleh besar diameter roda, jarak pitch spiral, kecepatan putar dan efesiensi pembebanan tegak lurus terhadap sumbu putar. Perhitungan bilah roda ini identik dengan konveyor screw yang diteliti oleh Robertus, A.W[12]. Kapasitas volumetrik aktual bilah spiral roda dicari melalui persamaan:

$Q_{a}=Q_{t} \eta_{V}$ 


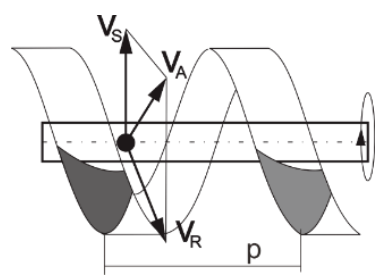

(a)

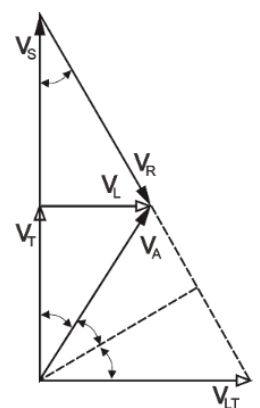

(b)

Gambar 3. Efisiensi vortek dihitung dengan pendekatan perbandingan segitiga kecepatan partikel tanah akibat menumbuk permukaan bilah roda dan bila diasumsikan tanahnya datar maka, $\beta=0$ dan $\phi_{\mathrm{s}}=$ $\alpha$. (a) Penampang melintang bilah roda spiral dengan penerapan segitiga kecepatan, (b) Segitiga kecepatan pada partikel tanah dan resultannya.

\section{keterangan,}

$V_{S}=$ kecepatan sentrifugal

$V_{R}=$ kecepatan resultan

$V_{A}=$ kecepatan aktual

$V_{T}=$ kecepatan transversal

$V_{L}=$ kecepatan longitudinal

$V_{L t}=$ kecepatan longitudinal teoritis

$\alpha=$ sudut antara tegak lurus bidang bilah roda dengan poros roda

Sedangkan $\eta_{V}$ adalah effisiensi volumetric tanah yang dipindahkan,

$\eta_{V}=\eta_{V R} \cdot \eta_{F}$

Di mana,

$\eta_{V R}=$ effisiensi vortek pada putaran bilah roda

$\eta_{F} \quad=$ kedalaman rata-rata dari permukaan tanah per panjang pitch, persen $\%$

Bila roda diasumsikan tertanam dengan variasi $20 \%, 40 \%$ dan $50 \%$, kemudian effesiensi vortek, $\eta_{V R}$ dihitung dengan pendekatan perbandingan segitiga kecepatan yang diakibatkan kemiringan menumbuk permukaan bilah roda. Lihat Gambar 3.

$\eta_{V R}=\frac{V_{L}}{V_{L t}}=\frac{\tan \lambda}{\tan \alpha+\tan \lambda}$

Sedangkan kapasitas volumetrik teoritis, $Q_{t}\left(\frac{m^{3}}{s}\right)$ diperoleh dari:
$Q_{t}=\frac{\pi}{4}\left(D_{s f}^{2}-D_{s s}^{2}\right) l_{p} n$

Keterangan:

$D_{s f} \quad=$ Diameter luar bilah roda spiral, $\mathrm{m}$

$D_{S S} \quad=$ Diameter poros, $\mathrm{m}$

$l_{p} \quad=$ Panjang pitch, $\mathrm{m}$

$n=$ Kecepatan putar bilah roda, putaran $/ \mathrm{s}$

Simulasi Analisa Finite Element FEA dan gerak partikel tanah mengunakan software CFD.

Pembebanan pada struktur bilah roda di sederhanakan modelnya menjadi sebuah pitch saja dengan panjang $100 \mathrm{~mm}$ agar efisiensi proses simulasi dapat lebih optimal dan hasilnya cukup akurat. Panjang masing-masing roda adalah $200 \mathrm{~mm}$ dan bila pada unit mini traktor terdapat 4 buah roda maka total terdapat 8 pitch. Sehingga beban yang diterapkan dalam simulasi 1/8 dari total beban untuk memindahkan atau membajak tanah yaitu 2,63 N. Lihat Gambar.4 (a).

Selain itu untuk mempelajari gerak partikel tanah simulasi di set seperti diilustrasikan pada gambar b. Geometri poros dan diameter luar disamakan dengan diameter dan poros roda minitraktor yang dijual di pasaran yaitu $15 \mathrm{~mm}$ dan $180 \mathrm{~mm}$. Hal ini untuk melihat posisi partikel tanah di mana yang tidak berpindah/tidak efektif berpindah hanya berputar. Seperti yang diilustrasikan pada Gambar 4.(b). 


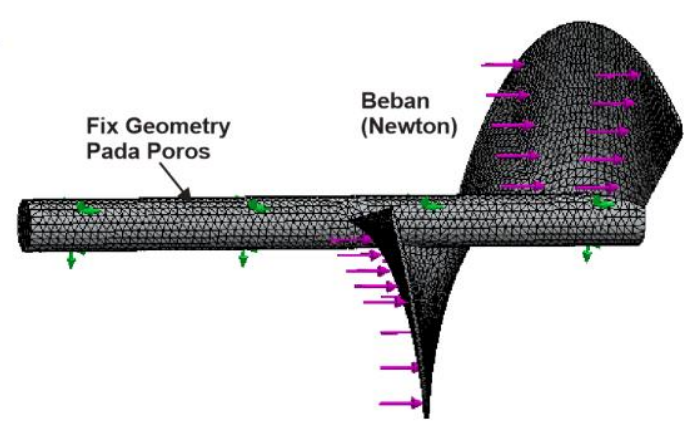

(a)

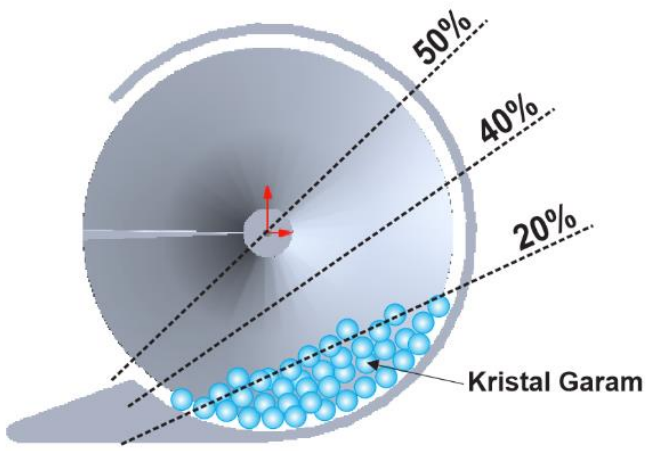

(b)

Gambar 4. Kondisi batas pada simulasi. (a) analisa FEA untuk mengetahui tegangan kritis dan defksi maksimum, material Baja karbon ST37, (b) analisa gerak partikel penampang melintang dengan variabel pembebanan tanah $20 \%$, 40\% dan 50\%.

\section{HASIL DAN DISKUSI}

Bila roda spiral memiliki keunggulan dapat beroperasi sama seperti prinsip kerja roda Mechanum. Kinerja bilah roda spiral dapat ditentukan seberapa besar efesiensi pemindahan tanah atau membajak tanah, kemudian berapa daya yang dibutuhkan untuk mengoperaisikannya akan dibahas pada gambar berikut.

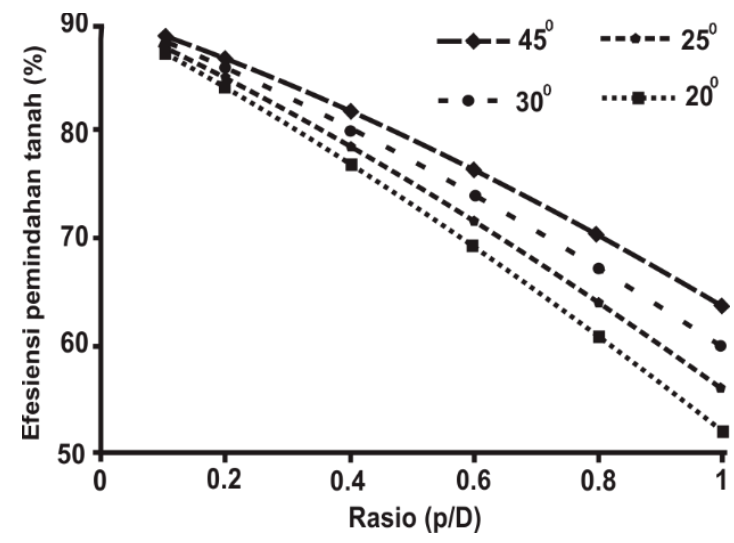

(a)

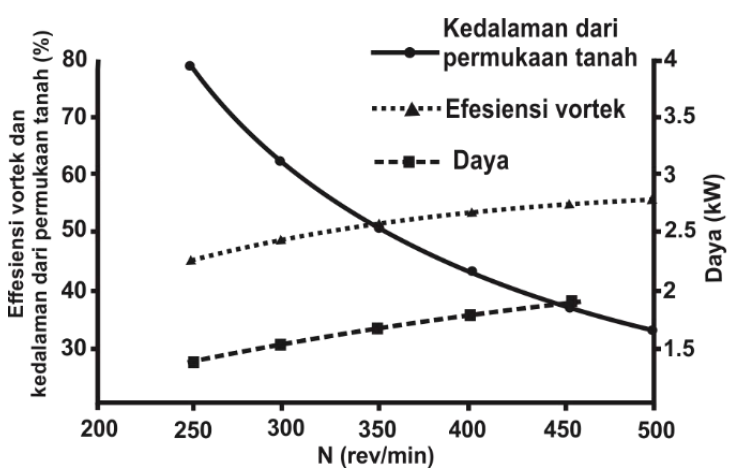

(b)

Gambar 5. (a) Grafik hubungan antara rasio jarak pitch/diamater roda terhadap efesiensi mepindahan tanah, (b) grafik hubungan antara kecepatan putar bilah roda minitraktor terhadap prosentase efesiensi vortek, prosentase kedalaman roda dari permukaan tanah dan daya yang dibutuhkan.

Pada gambar 5(a) menunjukkan grafik rasio panjang pitch per diameter luar sebuah bilah roda spiral terhadap efesiensi pemindahan tanah. Dimana dihitung terhadap variasi sudut kelengkungan bilah spiral terhadap poros roda. Pada sudut $45^{\circ}$ memiliki efesiensi tertinggi di semua rasio pitch/diameter dibanding sudut lainya. Hal ini terjadi karena tanah yang dipindahkan berada pada arah sejajar dengan poros roda. Kemudian seiring dengan meningkatnya rasio jarak Pitch/diamater maka efesiensi pemindahan tanah menurun. Trend line grafik ini sama seperti yang diteliti oleh Roberts.A W [12] Namun perbedaan panjang poros bilah roda spiral menyebabkan efesiensinya sedikit berbeda.

Demikian juga yang terjadi pada pengaruh kecepatan putar rodat erhadap efesiensi vortek, prosentase kedalaman dari permukaan tanah dan 
daya yang dibutuhkan, seperti yang ditunjukkan pada gambar 5 (b). Semakin cepat kecepatan putar bilah roda maka daya yang dibutuhkan meningkat namun tidak terlalu signifikan, hal ini disebabkan karena partikel tanah yang terngkat atau termakan lebih sedikit, sehingga tahanan putar akibat beban pengangkatan tanah sedikit, begitu juga sebaliknya. Fenomena yang sama terjadi pada prosentase efesiensi vortek di mana seiring meningkatnya kecepatan putar bilah roda maka efesiensi vortek meningkat. Semakin tinggi kecepatan putar maka kedalaman bilah yang dicapai dari permukaan tanah semakin sedikit hal ini disebabkan karena pemakanan menurun. Bilah roda terlalu cepat berputar hanya bergesekan dengan permukaan tanah belum sempat berada di posisi memotong atau mengangkat tanah .
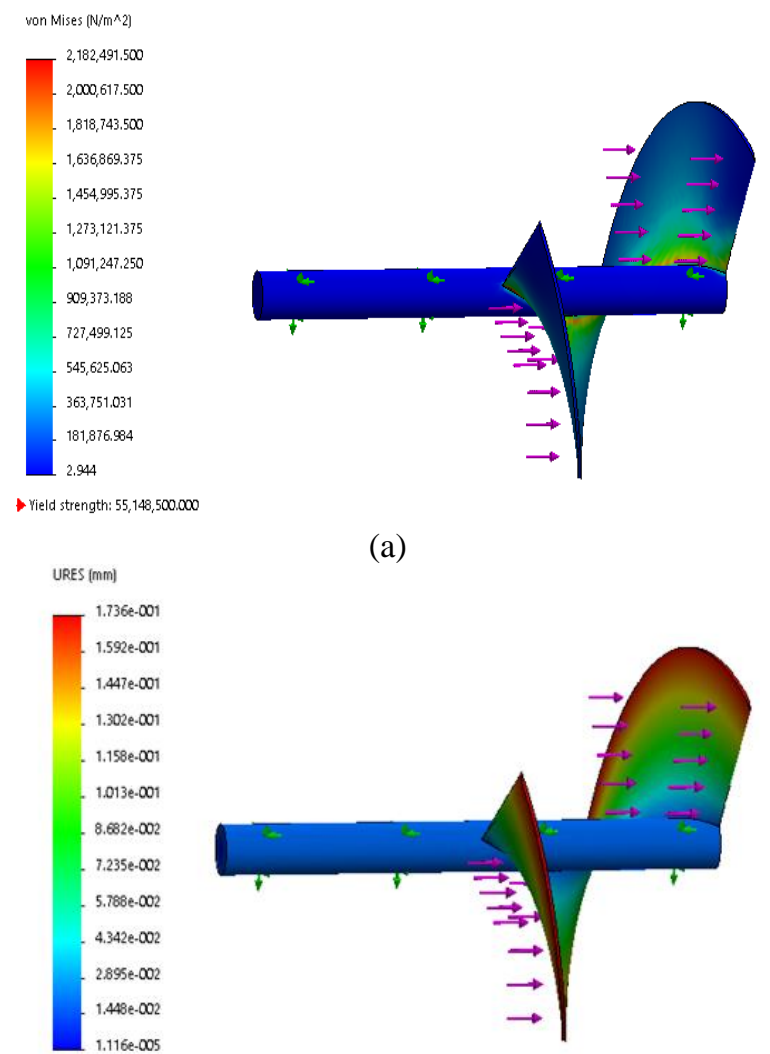

(b)

Gambar 6. (a) Distribusi tegangan Von Misses bilah. (b) Defleksi pada sebuah ulir, nilai maksimal terdapat pada bagian sisi tepi bilah roda minitraktor.

Pada Gambar 6 menampilkan pembebanan dengan bilah roda minitraktor dengan panjang pitch $100 \mathrm{~mm}$ dan pembebanan sebesar 2,63 $\mathrm{N}$ yang merupakan 1/8 dari total. Pada gambar 6(a) distribusi tegangan von misses, tegangan paling tinggi pada struktur roda terdapat pada bagian sambungan bilah roda dengan poros. Perbedaan ketebalan dan beban yang tinggi pada bagian tepi sisi roda mengakibatkan sambungan mengalami beban torsi tertinggi. Sambungan tersebut merupakan sambungan las dan secara keseluruhan masih berada batas aman. Pada Gambar 6(b). Distribusi defleksi struktur pada bilah roda, pada bagian ujung plat roda yang bersinggungan langsung dengan permukaan tanah memiliki defleksi paling besar. Plat bilah roda mini traktor memiliki ketebalan yang cukup sehingga mampu menahan beban maksimal.

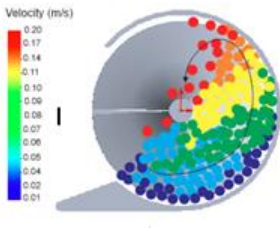

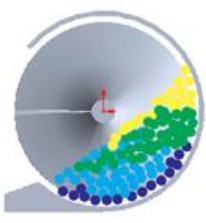

b

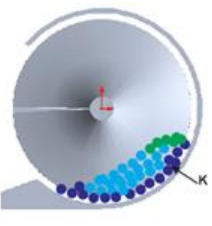

Gambar 7. Ilustrasi hasil simulasi dari potongan tengah Bilah roda minitraktor terhadap partikel tanah yang dipindahkan. (a) Sebagian bilah roda terbenam $50 \%$ di bawah permukaan tanah, (b) Sebagian bilah roda terbenam $40 \%$ di bawah permukaan tanah (c) Sebagian bilah roda terbenam $20 \%$ di bawah permukaan tanah,

Pada fenomena pergerakan partikel tanah Gambar.7, ketika bilah roda minitraktor dioperasikan, bilah roda bergerak berputar berlawanan arah jarum jam, bila kondisi partikel tanah cukup halus dan kering maka partikel tanah akan mudah mengalami slip dan tidak naik ke dinding silinder sehingga mudah dipindahkan. Hal itu terlihat pada warna merah partikel paling cepat bergerak. Hal ini menandakan bilah roda memiliki efesiensi pemindahan tanah atau membajak tanah dengan cukup efesien. Pada gambar 7 (c) kecepatan gerak partikel tanah relatif lambat tetapi partikel tanah masih bisa dipindahlan secepat bilah roda bergerak trasversal [13]. Namun terjadi masalah bila partikel tanah kasar atau tanah basah/liat. Sebagian partikel tanah akan ikut berputar dan memenuhi dinding silider mengakibatkan sulit 
dipindah dan pembebanan meningkat, sehingga effesiensi pemindahan menurun.

\section{KESIMPULAN}

Secara teoritis perhitungan kecepatan putar maksimal bilah roda spiral 450 putaran per menit akan dibutuhkan daya penggerak minitraktor sebesar $1.9 \mathrm{~kW}$ atau setara dengan $2.56 \mathrm{Hp}$ bila dipasang 4 buah roda. Hal ini masih sesuai dengan minitraktor sejenis dipasaran dengan daya $5 \mathrm{Hp}$. Kecepatan putar optimal terjadi pada kecepatan $350 \mathrm{rpm}$ dimana terjadi persinggungan antara kedalaman bilah roda terhadap permukaan tanah dan efesiensi vortek, sehingga daya optimal yang dibutuhkan $1.5 \mathrm{~kW}$. Selain itu pada sudut $45^{0}$ sudut kelengkungan bilah roda terhadap poros mencapai efisiensi pemindahan tanah atau membajak tanah tertinggi pada semua rasio pitch/diameter roda. Hasil simulasi dapat diketahui titik kritis terjadi pada sambungan plat bilah roda dengan poros roda dan defleksi maksimum terjadi pada ujung tepi luar roda. Sementara itu pada simulsi gerak partikel tertinggi dicapai ketika roda bilah tertanam 50\% dari permukaan tanah.

\section{DAFTAR PUSTAKA}

[1] J.G. Hendrick, \& W. R. Gill, "Rotary-Tiller Design Parameters Part I-Direction of Rotation." Transactions of the ASAE,,vol. 14, no. 4, pp. 669-674, 1971.

[2] M. Topakçı, H.K. Çelik,D. Yılmaz, \& I. Akıncı, Stress analysis on transmission gears of a rotary tiller using finite element method. Journal of the Faculty of Agriculture of Akdeniz University (Turkey), 2008.

[3] R. Cowan, D. Culpin, \& V.B. Morris, "A method for the measurement of variability in cell lifetimes." Mathematical Biosciences, vol. 54, no. 3-4, pp. 249-263, 1981.

[4] A. D. Dalin, \& P. V. Pavlov, Rotary tillering and earth-moving machines. Moscow: Mashgiz, 1950. 258 p. 1950.

[5] Y. E. Zhuk, Studies of rotary tilling soil, 1952.

[6] S. K. Mandal, A. Maity, \& A.K. Prasad, "Performance Evaluation of a Lightweight Power Tiller." Agriculture for Sustainable Development, vol. 3-4, pp. 126-139, 2016.
[7] Y. Liu, J.J. Zhu,R.L. Williams II, \& J. Wu, “Omnidirectional mobile robot controller based on trajectory linearization." Robotics and autonomous systems, vol. 56, no. 5, pp. 461-479, 2008.

[8] O. Diegel, A. Badve, G. Bright, J. Potgieter, \& S. Tlale, "Improved mecanum wheel design for omni-directional robots." In Proc. 2002 Australasian conference on robotics and automation, Auckland,pp. 117-121, 2002.

[9] J. E. M. Salih, M. Rizon, S. Yaacob, A. Adom, \& M. R. Mamat, "Designing omni-directional mobile robot with mecanum wheel." American Journal of Applied Sciences, vol. 3, no. 5, pp. 1831-1835, 2006.

[10] N. Tlale, \& M. de Villiers, "Kinematics and dynamics modelling of a mecanum wheeled mobile platform." In 2008 15th International Conference on Mechatronics and Machine Vision in Practice, pp. 657-662, 2008.

[11] J. Jeong, S. J. Kwon, B. Chu, \& J. Park, "Unifiedtype design and structural analysis for mecanum wheel performance improvement." Journal of the Korean Society of Manufacturing Process Engineers, vol. 13, no. 2, pp. 117-123, 2014.

[12] A. W. Roberts, "The influence of granular vortex motion on the volumetric performance of enclosed screw conveyors." Powder Technology, vol. 104, no. 1, pp. 56-67, 1999.

[13] A. Degirmencioglu, \& A. K. Srivastava, "Development of screw conveyor performance models using dimensional analysis." Transactions of the ASAE, vol. 39, no. 5, pp. 1757-1763, 1996. 